BIODIK: Jurnal IImiah Pendidikan Biologi
ISSN 2580-0922 (online), ISSN 2460-2612 (print)
Volume 6, Nomor 04, Tahun 2020, Hal. 411-422
Available online at:
https://online-journal.unja.ac.id/biodik

Research Article

open 2 Access

\title{
Analisis Kualitas Struktur Pada Lembar Kegiatan Siswa Materi Uji Makanan
}

\author{
(Analysis of the Quality Structure on the Student Worksheet on Food Test Materials)
}

\author{
Silvia Sukma Putri, Bambang Supriatno, Sri Anggraeni \\ Universitas Pendidikan Indonesia \\ JI. Dr. Setiabudi No.229, Isola, Kec. Sukasari, Kota Bandung, Jawa Barat 40154 \\ Corresponding Author: ss.sukmaputri01@gmail.com
}

\begin{tabular}{|c|c|}
\hline Informasi Artikel & ABSTRACT \\
\hline $\begin{array}{l}\text { Submit: } 24-06-2020 \\
\text { Diterima: } 02-09-2020 \\
\text { Dipublikasikan: } 07-12-2020\end{array}$ & $\begin{array}{l}\text { This study aims to determine the completeness structure and quality of worksheets, } \\
\text { based on Vee diagram and describe the results of the analysis. In addition, the } \\
\text { purpose of this study describes the reconstruction towards the Student Worksheet } \\
\text { based on the objectives, practicum process and questions that form the basis of this } \\
\text { study. This research is a qualitative descriptive study with total sampling technique. } \\
\text { The subjects were } 10 \text { worksheets contained in the biology textbook class XI food test } \\
\text { material. The result of analysis the Student Worksheet found confusing work steps, } \\
\text { the amount of food used, recording data not in accordance with the work steps } \\
\text { carried out, repetition of tests with known contents, determination of practicum time, } \\
\text { errors in each test could not be avoided if practicum less thorough, and discoloration } \\
\text { that is not according to the expected procedure. In general, student worksheet of } \\
\text { Food Test refers to instruments based on Vee Diagrams which analyze the } \\
\text { conceptual, procedural, and knowledge construction aspects. The results of Vee } \\
\text { diagram component analysis on } 10 \text { worksheets that appeared were focus questions, } \\
\text { objects / events, as well as theories / principles / concepts, while the record I } \\
\text { transformation component, and claim knowledge had not yet appeared. On average, } \\
10 \text { student worksheets analyzed didn't form an ideal claim knowledge, however the } \\
\text { construction of the student worksheet knowledge could be improved. } \\
\text { Keywords: : Student Worksheet, Vee Diagram, Knowledge Construction, Food Test, } \\
\text { Student Worksheet Content }\end{array}$ \\
\hline Penerbit & ABSTRAK \\
\hline $\begin{array}{l}\text { Program Studi Pendidikan } \\
\text { Biologi, Fakultas Keguruan dan } \\
\text { Ilmu Pendidikan, Universitas } \\
\text { Jambi }\end{array}$ & $\begin{array}{l}\text { Penelitian ini bertujuan untuk mengetahui struktur kelengkapan dan kualitas LKS, } \\
\text { berdasarkan diagram Vee dan mendeskripsikan hasil analisis. Selain itu, tujuan } \\
\text { penelitian ini mendeskripsikan tentang rekonstruksi terhadap Lembar Kerja Siswa } \\
\text { berdasarkan tujuan, proses praktikum dan pertanyaan yang dijadikan dasar dalam } \\
\text { penelitian. Penelitian ini merupakan penelitian deskriptif kualitatif dengan teknik total } \\
\text { sampling. Subjek dalam penelitian ini adalah } 10 \text { LKS yang terdapat di dalam buku } \\
\text { paket biologi kelas XI materi uji makanan. Hasil analisis uji Langkah kerja Lembar } \\
\text { Kerja Siswa ditemukan petunjuk langkah kerja yang kurang tepat, jumlah bahan } \\
\text { makanan yang digunakan, perekaman data tidak sesuai dengan langkah kerja yang } \\
\text { dilakukan, pengulangan pengujian yang sudah diketahui kandungannya, penentuan } \\
\text { waktu praktikum, kesalahan pada setiap uji tidak bisa terelakkan jika praktikum } \\
\text { kurang teliti, serta perubahan warna yang tidak sesuai prosedur yang diharapkan. } \\
\text { Secara umum LKS Uji makanan mengacu pada Instrumen berdasarkan Diagram Vee } \\
\text { yang menganalisis segi konseptual, prosedural, dan kontruksi pengetahuan. Hasil } \\
\text { analisis komponen diagram Vee pada } 10 \text { LKS yaitu pertanyaan fokus, objek atau } \\
\text { event, serta teori atau prinsip atau konsep, sedangkan komponen } \\
\text { record/transformation, dan claim knowledge belum muncul. Rata-rata } 10 \text { LKS yang } \\
\text { dianalisis belum membentuk claim knowledge yang ideal namun kontruksi } \\
\text { pengetahuan Lembar Kerja Siswa dapat ditingkatkan. } \\
\text { Katakunci: Lembar Kegiatan Siswa, Diagram Vee, Konstruksi Pengetahuan, Uji } \\
\text { Makanan, Konten LKS }\end{array}$ \\
\hline
\end{tabular}




\section{PENDAHULUAN}

Tantangan abad 21 adalah Sains khususnya Biologi, karena memiliki kontribusi yang cukup besar dalam perkembangan teknologi, yakni sebagai ilmu dasar yang melandasi pengembangan teknologi. Menurut Liliasari (2011) berpendapat bahwa sains sangat penting dalam segala aspek kehidupan, karena itu perlu dipelajari agar semua insan Indonesia (Science literacy community) namun tetap berkarakter bangsa. Menurut Anderson (2014) menyatakan bahwa tren pembelajaran sains abad 21 idealnya diarahkan pada 4 komponen yakni: Communication, Collaboration, Critical thinking \& Problem solving, creativity \& innovation. Pembelajaran diarahkan pada penciptaan suasana aktif, kritis, analisis, dan kreatif dalam pemecahan masalah melalui pengembangan kemampuan berpikir (BSNP/Depdiknas, 2006).

Praktikum Biologi merupakan kegiatan pembelajaran yang bertujuan agar siswa mendapat kesempatan untuk menguji dan mengaplikasikan teori dengan menggunakan fasilitas laboratorium maupun di luar laboratorium. Praktikum dalam pembelajaran Biologi merupakan metode yang efektif untuk mencapai tujuan pembelajaran (Rustaman, 2005:135). Menurut Permendiknas no.21 tahun 2016 beberapa kompetensi yang harus dicapai siswa dalam pelajaran Biologi yaitu menerapkan proses kerja di laboratorium dalam pengamatan dan percobaan untuk memahami permasalahan Biologi pada berbagai objek, mengkomunikasikan hasil pengamatan dan percobaan secara lisan maupun tulisan, menyajikan data berbagai objek berdasarkan pengamatan dan percobaan dengan menerapkan prosedur ilmiah. Menurut Millar (2004) mengatakan bahwa kegiatan prakitkum berperan untuk membantu siswa menghubungkan antara dua ranah pengetahuan, yaitu objek atau fenomena yang teramati dan ranah gagasan atau ide.

Dalam kegiatan praktikum memerlukan suatu pedoman agar siswa dapat memperoleh pengetahuan melalui proses pengalaman. Pedoman yang dapat membantu siswa untuk mendapatkan pengalaman belajar tersebut adalah Lembar Kerja Siswa (LKS) (Rohaeti, et al. 2006). Lembar Kerja Siswa (LKS) merupakan lembar kerja yang berisi informasi dan perintah/intruksi dari guru kepada siswa dalam bentuk kerja, praktikum, atau dalam bentuk penerapan hasil belajar untuk mencapai suatu tujuan (Aris, 2014). Namun pada kenyataannya, LKS yang ada dilapangan masih memiliki permasalahan. Menurut Supriatno (2009) permasalahan yang ada dilapangan menemukan $24 \%$ LKS yang dapat dikerjakan dengan hasil sesuai prosedur dan tuntas dari segi analisis data dan penarikan kesimpulan. Selain itu, penelitian sebelumnya yang dilakukan oleh Supriatno et al. (2009) menunjukkan bahwa kegiatan laboratorium yang dirancang dalam bentuk Lembar Kerja Siswa (LKS) yang saat ini beredar dilapangan dan digunakan di sekolah-sekolah memiliki permasalahan yaitu, langkah desain langkah kerja yang salah, tidak tepat, tidak 
terstruktur, menimbulkan beragam penafsiran atau metodologi yang juga tidak benar. Hal ini jelas akan mempengaruhi penarikan kesimpulan yang dilakukan siswa karena kesimpulan harus sesuai dengan tujuan praktikum.

Berdasarkan permasalahan yang telah diungkap, maka diperlukan LKS yang dapat membantu siswa dalam mengkontruksi pengetahuannya, memberikan kontribusi terhadap pengembangan keterampilan dasar sains siswa, serta mengembangka kemampuan berpikir siswa. Kerangka berpikir menurut Novak \& Gowin (1984) yaitu Diagram Vee yang memiliki dimensi pengetahuan di sisi kiri dan dimensi pengalaman/kegiatan di sisi kanan. Pada saat siswa melakukan praktikum kedua dimensi saling berinteraksi satu sama lain melalui pertanyaan fokus yang mengarahkan siswa pada objek atau peristiwa yang harus diobservasi untuk membentuk pengetahuan yang sesuai. Menurut Alvarez dan Risko (2007) menunjukkan bahwa Diagram Vee merupakan alat yang layak untuk mempelajari struktur pengetahuan dan proses mendapatkan pengetahuan.

Berdasarkan kurikulum yang berlaku di SMA, materi uji makanan dituntut untuk diajarkan dengan kegiatan praktikum. Materi Uji Makanan merupakan salah satu materi yang cukup sering dilakukan disekolah. Hal ini dikarenakan materi uji makanan bersifat abstrak sehingga memerlukan ketelitian dalam praktikum, selain itu praktikum ini mempunyai keterkaitan dengan konsumsi makanan sehari-hari. Untuk mengamati produk hasil uji makanan dapat diobservasi melalui beberapa uji, yaitu uji protein, uji lemak, glukosa, dan amilum (untuk mengobservasi kandungan zat pada setiap bahan makanan). Namun peneliti, merasa ada beberapa prosedur yang harus ditinjau ulang terkait dengan praktikum uji makanan yang digunakan pada jenjang SMA.

\section{METODE PENELITIAN}

Metode penelitian yang digunakan dalam penelitian ini adalah deskriptif kualitatif. Penelitian ini diharapkan dapat memberikan gambaran mengenai kelengkapan dan kualitas Lembar Kegiatan Praktikum (LKS) materi Uji Makanan yang digunakan pada janjang SMA. Sampel yang diambil dalam penelitian ini yaitu 10 sampel LKS SMA. Teknik sampling dilakukan secara total, karena Lembar Kerja Siswa yang didapatkan keseluruhan digunakan dan dianalisis. Instrumen yang digunakan yaitu berupa tabel komponen diagram Vee, tabel penskoran diagram Vee yang diadaptasi dari Novak dan Gowin (1984) kontruksi pengetahuan, tabel penskoran konseptual dan prosedural berdasarkan instrumen. Analisis yang dilakukan pada DKL ini dengan cara menganalisis komponen-komponen apa saja yang tidak sesuai dengan Desain Kegiatan Laboratorium yang nantinya melakukan rekonstruksi dalam DKL tersebut. 


\section{HASIL DAN PEMBAHASAN}

\section{Analisis Uji Langkah Kerja LKS}

Masalah yang muncul dari hasil analisis dan uji coba 10 Lembar Kegiatan Siswa (LKS) materi uji makanan masalah yang muncul adalah petunjuk langkah kerja yang membingungkan, jumlah bahan makanan yang digunakan, perekaman data tidak sesuai dengan langkah kerja yang dilakukan, pengulangan pengujian yang sudah diketahui kandungannya, penentuan waktu praktikum, kesalahan pada setiap uji tidak bisa terelakkan jika praktikum kurang teliti, serta perubahan warna yang tidak sesuai prosedur yang diharapkan.

Permasalahan tentang petunjuk langkah kerja dan prosedur langkah kerja yang membingungkan sejalan dengan penelitian Supriatno (2013) yang menyatakan bahwa prosedur praktikum meskipun rinci, beberapa diantaranya tidak terstruktur dan perintahnya membingungkan sehingga menimbulkan penafsiran ganda. Selain itu penentuan waktu praktikum yang digunakan terkadang tidak sesuai dengan keadaan yang sebenarnya, kebanyakan guru belum melakukan pengujian personal sebelum diuji cobakan pada siswa. Temuan ini sesuai dengan penelitian oleh Hofstein \& Lunetta (2004) mengungkapkan bahwa fenomena penggunaan waktu praktikum yang dihabiskan untuk kegiatan teknis merupakan fenomena yang banyak terjadi dalam praktikum. Hal ini yang menyebabkan praktikum tidak bisa memberikan peran besar bagi peningkatan pemahaman siswa. Pengulangan pengujian bahan makanan yang sudah diketahui sebelumnya tidak memberikan pengalaman konsep baru untuk siswa. Hal ini sesuai dengan temuan Widodo \& Ramadhaningsih (2006) bahwa keseluruhan praktikum yang dilakukan merupakan bentuk praktikum yang bertujuan memberikan pengalaman pengamatan konsep baru untuk siswa. Permasalahan-permasalahan pada 10 Lembar Kegiatan Siswa (LKS) diatas, lebih dominan pada prosedur dan langkah kerja yang dilakukan belum rinci dan lengkap yang berpengaruh pada objek/event yang merupakan aspek penting untuk menuntut siswa pada kemunculan fakta dan fenomena saat praktikum.

Menurut Supriatno (2009) bahwa desain kegiatan laboratorium yang digunakan disekolah banyak yang diadopsi, tanpa adaptasi dan rekonstruksi. Pernyataan tersebut selaras dengan masalah dalam pemilihan dan pembuatan sebuah Lembar Kerja Siswa (LKS) khususnya materi uji makanan.

\section{Analisis Konseptual Lembar Kerja Siswa (LKS) Materi Uji Makanan}

Dari segi kesesuain konten kegiatan laboratorium dengan kurikulum yang berlaku dari beberapa parameter yang ada, dari 10 LKS yang dianalisis hanya beberapa LKS saja yang keterlaksanaan kegiatan praktikum sangatlah ideal. Penjelasan tersebut dapat dilihat pada (Tabel 1). 
Tabel 1 . Kesesuaian Kegiatan Laboratorium dengan kurikulum

\begin{tabular}{|c|c|c|c|c|c|c|c|c|c|c|c|}
\hline \multirow{2}{*}{ No. } & \multirow{2}{*}{ Parameter } & \multicolumn{10}{|c|}{ Kode LKS } \\
\hline & & P1 & $\mathrm{P} 2$ & P3 & P4 & P5 & P6 & P7 & P8 & P9 & P10 \\
\hline 1. & $\begin{array}{ll}\begin{array}{l}\text { Kesesuaian } \\
\text { dengan KD }\end{array} & \text { konten } \\
\end{array}$ & - & - & - & - & - & - & - & - & - & - \\
\hline 2. & $\begin{array}{ll}\text { Kesesuaian } & \text { Kompetensi } \\
\text { dengan KD }\end{array}$ & - & - & - & - & - & - & - & - & - & - \\
\hline 3. & $\begin{array}{l}\text { Kesesuaian Judul dengan } \\
\text { Kegiatan }\end{array}$ & - & - & - & $\sqrt{ }$ & $\sqrt{ }$ & $\sqrt{ }$ & - & - & $\sqrt{ }$ & $\sqrt{ }$ \\
\hline 4. & $\begin{array}{lc}\text { Kesesuaian } & \text { Tujuan } \\
\text { dengan Langkah Kerja }\end{array}$ & $\sqrt{ }$ & $\sqrt{ }$ & $\sqrt{ }$ & $\sqrt{ }$ & $\sqrt{ }$ & $\sqrt{ }$ & $\sqrt{ }$ & $\sqrt{ }$ & $\sqrt{ }$ & $\sqrt{ }$ \\
\hline 5. & $\begin{array}{l}\text { Kesesuaian } \\
\text { dengan tingkat kegiatan } \\
\text { siswa }\end{array}$ & - & - & - & - & - & - & - & - & - & - \\
\hline
\end{tabular}

Hasil penelitian menunjukkan pada (Tabel 1) bahwa kesesuaian konten dengan Kompetensi Dasar pada 10 LKS yang ada semuanya tidak sesuai dengan kurikulum yang diharapkan. Semua LKS kegiatannya hanya membahas mengenai kandungan yang terdapat dari berabagi bahan makanan, sedangkan KD yang diharapkan dapat mengaitkannya dengan proses pencernaan serta bioprosesnya sehingga siswa dapat mendapat konsep tentang gangguan yang terjadi pada sistem pencernaan. Untuk Kesesuaian kompetensi dengan Kompetensi dasar 10 LKS tersebut hanya menuntut siswa untuk mengetahui kandungan zat makanan dari berbagai jenis bahan makanan saja, tanpa ada kaitan dengan sistem pencernaan. Untuk kesesuaian judul dengan kegiatan hanya 5 LKS yang sesuai dengan kegiatan praktikum yang dilakukan, 5 LKS lagi hanya tidak ada kesinambungan antara judul dengan kegiatan. Selanjutnya kesesuaian tujuan dengan langkah kerja, semua LKS sudah sesuai antara tujuan dengan langkah kerja yang dilakukan. Dan yang terakhir kesesuaian kegiatan dengan tingkat kognitif, semua LKS tidak diperuntukkan untuk SMA, siswa SMA harusnya harus sampai menganalisis, menginterpretasi, mengimplementasikan, hingga akhirnya menyajikan sebuah laporan terkait kandungan zat makanan pada berbagai bahan makanan. Praktikum ini hanya sampai pada mengetahui, bahwa siswa mengetahui kandungan zat makanan pada bahan makanan. Hasil pembahasan diatas, sesuai dengan temuan Woolnough (dalam N, Rustaman et al., 2003) bahwa hasil validasi instrument, komponen tujuan dianalisis mengenai aspek mengacu tidaknya tujuan praktikum terhadap indikator, ketergambaran tujuan dalam langkah kegiatan, ketercapaian tujuan, serta kategori tujuan praktikum.

\section{Analisis Prosedural Lembar Kerja Siswa (LKS) Materi Uji Makanan}

Dari segi keterlaksanaan kegiatan secara laboratorium dalam menghadirkan objek/fenomena terdapat pada (Tabel 2). 
Tabel 2. Keterlaksanaan Kegiatan Laboratorium

\begin{tabular}{|c|c|c|c|c|c|c|c|c|c|c|c|}
\hline \multirow[t]{2}{*}{ No. } & \multirow[t]{2}{*}{ Parameter } & \multicolumn{10}{|c|}{ Kode LKS } \\
\hline & & P1 & P2 & P3 & P4 & P5 & P6 & P7 & P8 & P9 & P10 \\
\hline 1. & $\begin{array}{l}\text { Alat-alat sesuai } \\
\text { standar sekolah }\end{array}$ & $\sqrt{ }$ & $\sqrt{ }$ & $\sqrt{ }$ & $\sqrt{ }$ & $\sqrt{ }$ & $\sqrt{ }$ & $\sqrt{ }$ & $\sqrt{ }$ & $\sqrt{ }$ & $\sqrt{ }$ \\
\hline 2. & $\begin{array}{l}\text { Bahan praktikum } \\
\text { mudah didapat }\end{array}$ & $\sqrt{ }$ & $\sqrt{ }$ & $\sqrt{ }$ & $\sqrt{ }$ & $\sqrt{ }$ & $\sqrt{ }$ & $\sqrt{ }$ & $\sqrt{ }$ & $\sqrt{ }$ & $\sqrt{ }$ \\
\hline 3. & Langkah terstruktur & $\sqrt{ }$ & $\sqrt{ }$ & $\sqrt{ }$ & $\sqrt{ }$ & $\sqrt{ }$ & $\sqrt{ }$ & $\sqrt{ }$ & $\sqrt{ }$ & $\sqrt{ }$ & $\sqrt{ }$ \\
\hline 4. & $\begin{array}{l}\text { Langkah mudah } \\
\text { dieksekusi }\end{array}$ & - & - & $\sqrt{ }$ & $\sqrt{ }$ & $\sqrt{ }$ & $\sqrt{ }$ & $\sqrt{ }$ & $\sqrt{ }$ & $\sqrt{ }$ & $\sqrt{ }$ \\
\hline 5. & $\begin{array}{l}\text { Objek/fenomena } \\
\text { muncul }\end{array}$ & $\sqrt{ }$ & $\sqrt{ }$ & $\sqrt{ }$ & $\sqrt{ }$ & $\sqrt{ }$ & $\sqrt{ }$ & $\sqrt{ }$ & $\sqrt{ }$ & $\sqrt{ }$ & $\sqrt{ }$ \\
\hline 6. & $\begin{array}{l}\text { Objek/fenomena } \\
\text { mudah diamati }\end{array}$ & $\sqrt{ }$ & $\sqrt{ }$ & $\sqrt{ }$ & $\sqrt{ }$ & $\sqrt{ }$ & $\sqrt{ }$ & $\sqrt{ }$ & $\sqrt{ }$ & $\sqrt{ }$ & $\sqrt{ }$ \\
\hline 7. & $\begin{array}{l}\text { Terdapat perekaman } \\
\text { data }\end{array}$ & $\sqrt{ }$ & $\sqrt{ }$ & $\sqrt{ }$ & $\sqrt{ }$ & - & - & - & - & - & $\sqrt{ }$ \\
\hline 8. & $\begin{array}{l}\text { Bentuk perekaman } \\
\text { data }\end{array}$ & $\sqrt{ }$ & $\sqrt{ }$ & $\sqrt{ }$ & $\sqrt{ }$ & - & $\sqrt{ }$ & $\sqrt{ }$ & $\sqrt{ }$ & $\sqrt{ }$ & $\sqrt{ }$ \\
\hline 9. & \begin{tabular}{l}
\multicolumn{2}{l}{ Objek/fenomena } \\
relevan dengan \\
judul/tujuan
\end{tabular} & - & - & - & - & - & - & - & - & $\sqrt{ }$ & $\sqrt{ }$ \\
\hline 10. & $\begin{array}{ll}\text { Waktu } & \text { yang } \\
\text { digunakan } & \end{array}$ & - & - & - & - & - & - & - & - & - & - \\
\hline 11. & Petunjuk safety lab & $\sqrt{ }$ & $\sqrt{ }$ & $\sqrt{ }$ & $\sqrt{ }$ & - & $\sqrt{ }$ & - & - & - & $\sqrt{ }$ \\
\hline 12. & Prosedur & $\sqrt{ }$ & $\sqrt{ }$ & $\sqrt{ }$ & $\sqrt{ }$ & - & $\sqrt{ }$ & - & - & - & $\sqrt{ }$ \\
\hline Kete & yan: & & & & & & & & & & \\
\hline
\end{tabular}

Berdasarkan (Tabel 2) diatas, dapat disimpulkan bahwa secara keseluruhan keterlaksanaan kegiatan laboratorium hampir sempurna. Namun dari seluruh LKS yang dianalisis dalam hal penggunaan waktu dalam kegiatan praktikum belum sesuai dengan keterlaksanaan dari kegiatan praktikum, harus ada peninjauan ulang terkait waktu dengan prosedur kegiatan praktikum. Pada 8 LKS objek/fenomena tidak muncul dikarenakan tidak sesuai antara judul dengan prosedur kerja yang dilakukan. Namun secara keseluruhan semua parameter dalam keterlaksanaan praktikum materi uji makanan sudah dikatakan ideal dan sesuai dengan standar kurikulum yang diterapkan.

\section{Analisis Konstruksi Pengetahuan Lembar Kerja Siswa (LKS) Materi Uji Makanan}

Komponen-komponen Diagram Vee yang dijaring dalam penelitian adalah pertanyaan fokus (focus question), objek atau peristiwa (object/events), konsep atau prinsip/teori (concept atau principles atau theories), catatan atau transformasi (records/transformation), dan klaim pengetahuan (knowledge claim). Komponenkomponen tersebut disajikan dalam Lembar Kerja Siswa yang telah dianalisis. Berdasarkan Gambar 1 diketahui bahwa komponen-komponen diagram Vee ditemukan hampir pada seluruh LKS. Pada 10 Lembar Kerja Siswa (LKS) yang telah dianalisis, komponen focus question pertanyaan fokus ditemukan hampir seluruh LKS dengan persentasi (\%) keberadaan tertinggi. 
Komponen object/events ditemukan hampir pada seluruh LKS dengan persentase (\%) yang sedikit lebih rendah daripada komponen focus question.Komponen (concepts atau principles atau theories) tidak ditemukan hampir pada seluruh Lembar Kerja Siswa. Gambar 1, juga menunjukkan Komponen (records/transformation) ditemukan pada beberapa LKS namun presentasi (\%) nya rendah dibandingkan dengan komponen (object/event), dan Komponen klaim pengetahuan (knowledge claim) persentasi (\%) pada ke 10 LKS sangat rendah

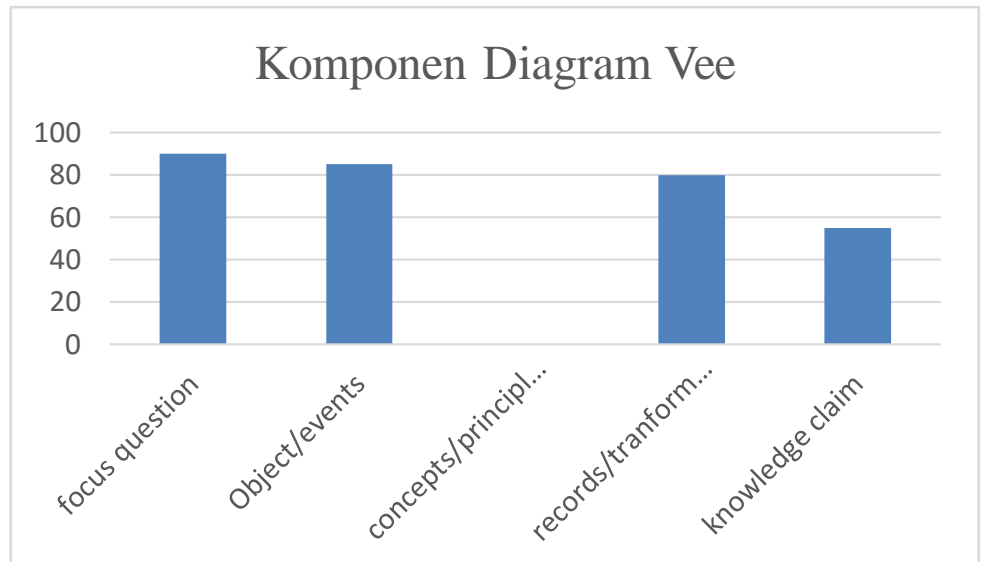

sekali jika dibandingkan dengan keempat komponen diagram Vee.

Gambar 1. Komponen Diagram Vee dalam Lembar Kerja Siswa

\section{Komponen focus question (Pertanyaan Fokus) pada Lembar Kerja Siswa}

Kualitas pertanyaan fokus (focus question) pada 10 LKS yang dianalisis dapat dilihat pada Tabel 3. Dari seluruh LKS yang memiliki pertanyaan fokus tidak seluruhnya mempunyai skor sempurna (skor 3). Pada Tabel 3, memperlihatkan bahwa LKS dengan pertanyaan fokus yang ditemukan pada tujuan praktikum, judul praktikum memiliki perolehan dengan (rata-rata skor total 1,8 ) kualitas yang lebih baik daripada yang hanya ditemukan dibagian judul praktikum saja atau tujuan praktikum saja. Hal ini dikarenakan pertanyaan fokus yang ditemukan di bagian tujuan praktikum diuraikan dalam satu atau beberapa kalimat sehingga dapat memuat penjelasan yang lebih rinci terkait dengan prosedur praktikum yang dicapai pada kegiatan laboratorium. Pernyataan ini didukung olek Millar \& Abraham (2009) yang mengemukakan bahwa pertanyaan fokus harus dinyatakan dengan jelas dan akurat agar kegiatan laboratorium dapat berjalan sesuai kurikulum.

\section{Kualitas Objects/events (Objek/peristiwa) pada Lembar Kerja Siswa}

Kualitas objek/peristiwa diseluruh LKS dapat dilihat pada (Tabel 3). Dari 10 LKS yang dianalisis yang memiliki komponen objek/peristiwa, hanya 3 LKS yang mendapatkan nilai sempurna (skor 3), yaitu LKS 4,5, dan 10 yang artinya ketiga LKS tersebut objek/peristiwa sesuai dengan apa yang ditulis dengan focus question. Tujuh (7) Lembar Kerja Siswa hanya mendapatkan (skor 2) yang artinya peristiwa utama disertai dengan objek dapat diidentifikasi dan konsisten dengan focus question. Rata-rata skor total dari 10 LKS yang dianalisis yaitu $(2,3)$. 
Hal ini sejalan dengan penelitian Supriatno et al. (2009) ketidak konsistenan tersebut disebabkan oleh berbagai permasalahan pada LKS, diantaranya adalah (1) kesalahan prosedur kerja atau prosedur kerja yang tidak lengkap; (2) pemilihan alat dan bahan yang tidak tepat; (3) penggunaan alat dan bahan yang jarang tersedia dilaboratorium standar Sekolah Menengah Atas (SMA), serta (4) tidak adanya pertanyaan fokus yang mendukung kemunculan objek/peristiwa. Berbagai penjelasan tersebut menjadi acuan tingkat keberhasilan dari objek/peristiwa yang memiliki skor rata-rata yang sedikit rendah.

\section{Kualitas Theory/principles/concepts (Teori/prinsip/konsep) pada Lembar Kerja Siswa}

Kualitas teori/prinsip/konsep pada 10 LKS pada jenjang SMA belum menunjukkan skor ideal. Rata-rata skor yang didapatkan adalah masih berada pada skor 2, yang artinya terdapat konsep dan setidaknya satu jenis prinsip (konseptual dan metodologis) atau konsep dan teori yang relevan dan dapat diidentifikasi. Sejalan dengan penelitian Dahar (2011) bahwa pengetahuan yang dapat diperoleh siswa melalui suatu pembelajaran/praktikum bergantung pada dua aspek yang saling berkaitan satu sama lain, yaitu siswa harus mengetahui tujuan dari kegiatan yang akan dilakukan, dan sampai seberapa jauh tujuan tersebut dapat dicapai oleh siswa. berbagai penjelasan tersebut menjadi acuan dalam prosedur kegiatan prakitkum yang ideal.

\section{Kualitas Record/transformations (Catatan/Transformasi) pada Lembar Kerja Siswa}

Kualitas catatan/transformasi di seluruh LKS yang dianalisis, tidak mendapatkan skor sempurna, rata-rata skor yang didapatkan yaitu (skor 1) yang artinya kegiatan pencatatan dapat diidentifikasi tetapi tidak konsisten dengan pertanyaan utama atau kegiatan utama yang disajikan. Temuan ini menandakan bahwa LKS yang memiliki komponen pencatatan yang disertai dengan transformasi tidak konsisten dengan pertanyaan fokus. Sejalan dengan pernyataan Trianto dalam Suyaningsih (2017) bahwa Sains atau IImu Pengetahuan alam (IPA) termasuk didalamnya Biologi merupakan ilmu pengetahuan yang tersusun atas 3 komponen penting berupa konsep, prinsip dan teori. Penjelasan diatas dapat dilihat pada (Tabel 2).

\section{Kualitas Knowledge claim (Klaim Pengetahuan) pada Lembar Kerja Siswa}

Kualitas komponen klaim pengetahuan diseluruh LKS hanya 5 LKS yang mendapatkan (skor 2) yang artinya knowledge claim tidak konsisten dengan data dan atau peristiwa yang dicatat dan ditransformasikan atau knowledge clai sudah mengandung conceptual side. 5 LKS mendapatkan (skor 1) yang artinya LKS tersebut tidak mempunyai knowledge claim yang dapat diidentifikasi. Temuan ini sesuai dengan penelitian (Supriatno, 2013) bahwa adanya langkah kerja yang salah 
dalam suatu LKS dapat mengakibatkan tingkat efektivitas kerja menjadi berkurang. Penjelasan diatas dapat dilihat pada (Tabel 3).

Tabel 3. Penskoran Lembar Kerja Siswa sesuai dengan Diagram Vee

\begin{tabular}{|c|c|c|c|c|c|c|c|c|c|c|c|c|}
\hline \multirow[t]{2}{*}{ No. } & \multirow[t]{2}{*}{ Komponen Diagram Vee } & \multicolumn{10}{|c|}{ Kode LKS } & \multirow{2}{*}{$\begin{array}{l}\text { Jumlah } \\
\text { Total }\end{array}$} \\
\hline & & P1 & P2 & P3 & P4 & P5 & P6 & P7 & P8 & P9 & P10 & \\
\hline 1. & Focus question & 2 & 2 & 2 & 1 & 1 & 2 & 2 & 2 & 2 & 2 & 18 \\
\hline 2. & Object/events & 2 & 2 & 2 & 3 & 3 & 2 & 2 & 2 & 2 & 3 & 23 \\
\hline 3. & $\begin{array}{c}\text { Concepts/principles/theorie } \\
s\end{array}$ & 2 & 2 & 2 & 2 & 2 & 2 & 2 & 2 & 2 & 2 & 20 \\
\hline 4. & $\begin{array}{c}\text { Record/ } \\
\text { Transformation }\end{array}$ & 1 & 1 & 1 & 2 & 0 & 1 & 1 & 1 & 1 & 1 & 10 \\
\hline 5. & Knowledge Claim & 2 & 1 & 1 & 2 & 0 & 2 & 1 & 1 & 2 & 2 & 14 \\
\hline & Rata-rata & 1,8 & 1,6 & 1,6 & 2 & 1,2 & 1,8 & 1,6 & 1,6 & 1,8 & 2 & 17,0 \\
\hline
\end{tabular}

\section{KESIMPULAN}

Berdasarkan hasil analisis peneliti pada lembar kerja siswa (LKS) materi uji makanan yang digunakan pada jenjang SMA, dapat disimpulkan bahwa masih terdapat beberapa permasalahan. Permasalahan yang dialami saat pengujian uji makanan yaitu petunjuk langkah kerja yang membingungkan, jumlah bahan makanan yang digunakan, perekaman data tidak sesuai dengan langkah kerja yang dilakukan, pengulangan pengujian yang sudah diketahui kandungannya, penentuan waktu praktikum, kesalahan pada setiap uji tidak bisa terelakkan jika praktikum kurang teliti, serta perubahan warna yang tidak sesuai prosedur yang diharapkan. Permasalahan-permasalahan yang muncul dapat mempengaruhi struktur diagram Vee terutama pada komponen object/event. Jika focus question dan object/event tidak mendapatkan skor ideal yaitu 3, maka tidak akan mungkin claim knowledge muncul dan memiliki skor 4. Pada umumnya struktur Lembar Kerja Siswa (LKS) materi Uji Makanan yang digunakan SMA harus adanya rekontruksi kembali mengacu pada struktur diagram Vee yaitu analisis konseptual, praktikal, dan konstruksi pengetahuan yang didalamnya mengandung focus question, Object/event, theory/principles/concepts, recods/transformation, dan knowledge claim. Dari 10 LKS yang dianalisis kelima komponen diagram Vee dapat dikatakan kurang ideal, karena ada beberapa komponen yang sama belum mencapai skor yang seharusnya pada sebuah keterlaksaan praktikum dan belum menunjang dalam proses konstruksi pengetahuan.

\section{DAFTAR PUSTAKA}

Abraham, I. (2009). Does practical work really motivate? A study of the affective value of practical work in secondary school science. International Journal of Science

Education.

31

(17),

2335-2352.

https://doi.org/10.1080/09500690802342836. 
Alvarez \& Risko. (2007). The Use Of Vee Diagrams With Third Graders As A Metcognitive Tool For Learning Science Concepts. Departmen of Teaching and Learning Presentations: Tennessee State University.

Aris, F. (2014). Kelayakan Teoritis Lembar Kegiatan Siswa Berbasis Pemecahan Masalah pada Materi Pengolahan Limbah. Jurnal Bioedu Berkala IImiah Pendidikan Biologi, 3(3), 431-436. BSNP. (2006), Panduan Penyusunan Kurikulum Tingkat Satuan Pendidikan Jenjang Pendidikan Dasar dan Menengah, BSNP Jakarta.

Dahar, R.W. (2011) Teori-teori Belajar. Jakarta: Erlangga.

Hofsten, A. \& Lunetta, V.N. (2004). The Laboratory in Science Education: Foundation for the Twenty first Century. Science Education, 88, 28-54.

Laelasari,Iseu \& Supriatno, B. (2018). Analisis Komponen Penyusun Desain Kegiatan Laboratorium Bioteknologi. Jurnal Bioedukatika Universitas Ahmad Dahlan, Vol.6, Nomor 2, hal. 84-90.

Liliasari, (2011). Membangun Masyarakat Melek Sains Berkarakter Bangsa Melalui Pembelajaran. [Makalah] Seminar Nasional UNES Semarang.

Novak \& Gowin. (1984) Learning How to Laearn. New York: Cambridge University Press.

Ramadhayanti, et al. (2020). Analisis Kualitas Struktur dan keberadaan Literasi Kuantitatif pada Lembar Kerja Peserta Didik Biologi SMA. [Skripsi] Departemen Pendidikan Biologi FPMIPA Universitas Pendidikan Indonesia, 25-33.

Rohaeti, E. Widjayanti, E \& Padmaningrum, R.T. (2006). Pengembangan Lembar Kerja Peserta Didik (LKS) mata pelajaran sains kimia untuk SMP kelas VII, VIII,dan IX. Yogyakarta: Jurusan Pendidikan Kimia FPMIPA UNY.

Situmorang, et al. (2019). Pengembangan Lembar Kerja Siswa (lks) Berbasis Inkuiri

Terbimbing Pada sub Materi Uji Kandungan Zat Makanan. Jurnal Pelita Pendidikan, 7(1), 023-027.

Supriatno, B. (2009). Uji Langkah Kerja Laboratorium Sekolah. Proseding Seminar Nasional Biologi: Inovasi dan pendidikan Biologi dalam Pengembangan Sumber Daya Manusia, 255-261.

Supriatno, B. (2013). Pengembangan Program Perkuliahan Pengembangan Praktikum Biologi Sekolah Berbasis ANCORB untuk Mengembangkan Kemampuan Merancang dan Mengembangkan Desain Kegiatan Laboratorium. Disertasi Jurusan Pendidikan Biologi FPMIPA UPI: Tidak diterbitkan.

Suryaningsih, Yeni. (2017). Pembelajaran Berbasis Praktikum Sebagai Sarana Siswa untuk Berlatih Menerapkan Keterampilan Proses Sains dalam Materi Biologi. Program Studi Pendidikan Biologi Universitas Majalengka, 2(2), 4957.

ITrinanada, Winda. S. (2015). Analisis Struktur dan Kemungkinan Kemunculan Tingkat Kognitif pada Desain Kegiatan Laboratorium Materi Sel. [Skripsi] Departemen Pendidikan Biologi FPMIPA Universitas Pendidikan Indonesia. 
Wahidah, Nur Sopiah, Bambang S, Kusumastuti M.N. (2018). Analisis Struktur dan Kemunculan Tingkat Kognitif pada Desain Kegiatan Laboratorium Materi Fotosintesis.

Widodo, A \& Ramadhaningsih, V. (2006). Analisis Kegiatan Praktikum Biologi dengan Menggunakan Video. Metalogika. 9(2), 146-158. 